\title{
Components of Brand Equity: The Case of Bình Thuận Dragon Fruit
}

\author{
NGÔ THỊ NGỌC HUYỀN \\ University of Economics HCMC - huyenntn@ueh.edu.vn \\ NGUYẼ̃N VIẾT BẰNG \\ University of Finance - Marketing - bangk7@gmail.com \\ ĐINH TIÊN MINH \\ University of Economics HCMC - dinhtienminh@ueh.edu.vn
}

\section{ARTICLE INFO}

Article history:

Received:

May 23, 2014

Received in revised form June 26, 2014

Accepted:

Sep. 30, 2014

\section{Keywords:}

brand equity, Bình Thuận

dragon fruit.

\section{ABSTRACT}

The paper aims at testing the theoretical model of brand equity and developing a measure for brand equity of Bình Thuận dragon fruit and relationship between components of brand equity. The research results based on Structural Equation Modeling (SEM) demonstrate relationships between the following components of the brand equity of Bình Thuận dragon fruit: Brand awareness, perceived quality, brand associations and brand loyalty. The results also show that these components do affect the overall brand equity. 


\section{PROBLEM STATEMENT}

Dragon fruit is a specialty ranked $1^{\text {st }}$ out of 11 types of Vietnamese fruit with competitive advantage acknowledged by Ministry of Agriculture and Rural Development at the conference held in HCMC on June 7 2004. The fruit features high economic efficiency and considerably raises farmers' income in general, and in Bình Thuận Province in particular, it helps restructure agricultural crops and change the face of rural districts.

Dragon fruit yield during the past years has risen rapidly (from 141,283 tons in 2007 to 379,604 tons in 2012 counted as for 15,807 hectares of farmland) (Bình Thuận Office of Statistics, 2012). Yet, uneven quality and size of dragon fruit, lax control of food sanitation from production to consumption stages and irrational brand marketing programs prevent this product from creating a vivid image in consumers' mind and intense loyalty toward the product, accounting for its low value (Bình Thuận Department of Agriculture and Rural Development, 2010).

\section{THEORETICAL BASES ON BRAND EQUITY AND PROPOSED RESEARCH MODEL}

\subsection{Brand Equity}

The concept of brand equity dates back to the 1980s and has resulted in various definitions (Keller, 1993). According to Aaker (1991, 1996), brand equity is the added value endowed by a brand. While Blackston (1992) assumes that brand equity is consumer's viewpoints on the brand, Keller (1993) defines it as consumer's knowledge of the brand, which consists of two main components: (i) brand awareness; and (2) brand impressions. In his perspective, a brand demonstrates its high value merely when customers have much awareness of and/or favorable impressions of attributes provided by the brand. Simon \& Sullivan (1993) identify brand equity as incremental benefits, whereas Park \& Srinivasan (1994) analyze brand equity in its role as the difference between "an individual consumer's overall brand preference" and his or her preference for different attributes in particular. As a whole, most studies prove that brand equity is the added value from a product thanks to the existence of brand (Srivastava $\&$ Shocker, 1991).

On the analysis of brand equity, Lassar et al. (1995) propose two approaches in financial perspective and consumer's one:

Financial perspective: Brand equity is viewed as corporate equity. Simon \& Sullivan (1993) employ finance-based estimation technique to measure corporate brand equity, 
which isolates the value of brand equity from that of others. This technique divides the value of corporate shares into tangible and intangible equity and subsequently, separates brand equity from the intangible assets (Hoàng et al., 2010).

Consumer's perspective: Aaker (1996) suggests that brand equity is "a set of brand assets and liabilities linked to a brand name and symbol, which add to or subtract from the value provided by a product or service." Keller (1993) introduces two ways of measuring brand equity: direct and indirect. Indirect measurement is conducted through the identification of potential resources of brand equity by measuring consumer's brand awareness, brand attributes and relationships between brand associations, whereas direct measurement focuses on evaluating consumer's response to corporate marketing.

To Siverman et al. (1999), brand equity in consumer's perspective can be approached by two different viewpoints: (i) Consumer's cognition (i.e. brand awareness, brand associations, perceived quality, brand trust); and (ii) Consumer's behavior (brand loyalty and willingness to pay high prices).

In this study, consumer's cognition viewpoint is chosen for the analysis.

\subsection{Components of Brand Equity:}

Aaker $(1991,1996)$ suggests that brand equity can be measured by the following four components: (i) brand awareness; (ii) perceived quality; (iii) brand associations; and (iv) brand loyalty.

Keller (1993) explains that brand equity itself is consumer's knowledge of that brand, which comprises brand awareness and brand impressions.

Lassar et al. (1995) in a research on brand equity in consumer's perspective indicate that brand equity is an increase in consumer's perceived benefits, which consist of five components: (i) perceived quality; (ii) perceived value; (iii) brand impressions; (iv) brand trust; and (v) feelings about the brand.

Sharp (1995) proposes three brand components: (i) brand awareness; (ii) brand images; and (iii) relationships with customers.

According to Berry (2000), brand equity is made up of brand awareness and brand meanings.

Nguyễn \& Nguyễn (2011) find that brand equity of consumer goods (i.e. shampoo) in Vietnam's market involves three components: (i) perceived quality; (ii) brand awareness; and (iii) brand passions. 


\subsection{Proposed Model and Hypotheses}

Most researches into brand equity are mainly conducted in developed countries and/or on manufactured or consumer goods; hence, scales are inappropriate for Vietnamese fresh fruit. An empirical research accordingly is needed to measure the model and develop a fine measure for brand equity of Bình Thuận dragon fruit specifically. Based on these observations, the authors apply the model suggested by Aaker (1991, 1996), including the following four components: (i) brand awareness; (ii) brand associations; (iii) perceived quality; and (iv) brand loyalty due to its being most cited (Atilgan et al., 2005).

Brand Equity: As defined by Keller (1993), brand equity is consumer's knowledge of that brand. Brown (1991) assumes that brand equity is consumer's impressions of a brand, representing his or her whole awareness and considered as an incentive for their consumption or use of a certain product/service among a wide range of other competitive ones in the market. To Srivastava \& Shocker (1991), brand equity is deemed added benefits from a branded product.

Meanwhile, Edell (1993) and Yoo et al. (2000) believe that brand equity refers to consumers' different assessments of branded and unbranded products of identical attributes.

Overall, most of the previous studies imply that brand equity reveals choices based on consumer's will and affection for a brand among a set of other competing brands (Davis \& Doughlass, 1995). That is also a highlight that comprehensively explains brand equity as a result of corporate marketing efforts to build positive awareness and behaviors toward the brand as well as for intangible value that leads to consumers' choices.

Brand Awareness: Brand awareness, according to Aaker (1991), is the ability of potential consumers to recognize and recollect a brand as a structural component of a certain product. Thus, brand awareness reflects the power of a brand existing in consumer's mind (Hoàng et al., 2010). In addition, brand awareness denotes another consumer's ability to recognize and recollect a brand in a series of brands in the market (Aaker, 1991; Keller, 1993; Rossiter \& Percy, 1987). Keller (1993, 1998) also indicates that brand awareness plays a crucial role in consumer's decisions and includes both brand recognition and brand recollection.

When consumers decide to choose a particular brand, they should first of all be able to identify it; therefore, brand awareness is a primary criterion, depending on which 
consumers distinguish a brand from a series of competing brands (Nguyễn \& Nguyễn, 2011). Since brand awareness is a component of brand equity (Aaker, 1991, 1996; Keller, 1993, 1998; Yoo et al., 2000; Nguyễn \& Nguyễn, 2011), the authors propose $\mathrm{H}_{1}$ as given below:

\section{$H_{1}$ : Brand awareness directly affects brand equity (+).}

Brand Associations: As suggested by Aaker (1991, 1996), a brand association is anything attached in consumer's memory as regards the brand and brand image as a part of brand associations. Keller $(1993,1998)$ assumes that brand associations are information on a brand existing in an individual consumer's mind and it connotes brand meanings as for that consumer.

Furthermore, brand associations can be examined in all forms and attributes of a product or distinctive features of its own (Chen, 2001). Brand associations are supposed to be fundamental to purchase decisions and brand loyalty of consumers, and increase corporate value (Atilgan et al. 2005). Aaker (1991, 1996) also lists such benefits provided by brand associations as supporting the process of collecting and retrieving information, creating brand distinction and reasons to the purchase, inspiring positive feelings/attitudes toward the brand, and providing the basis for expansion.

Brand associations also create corporate value and likewise enhance brand value by assisting consumers with the differentiation of various brands, arouse positive feelings/attitudes in consumers' minds and suggesting plausible reasons to the purchase (Tong \& Hawley, 2009). A brand association is another component of brand equity (Aaker, 1991, 1996; Keller, 1993; Yoo et al., 2000; Nguyễn \& Nguyễn, 2011), which leads to the hypothesis $\mathrm{H}_{2}$ :

\section{$\mathrm{H}_{2}$ : Brand associations directly affect brand equity (+).}

Perceived Quality: Perceived Quality is defined as consumer's subjective perception of product quality (Zeithaml, 1988). Hoàng et al. (2010) indicate that perceived quality is consumer's perception of the possibility that a brand lives up to his or her expectations. However, the authentic quality of a brand offered by a particular provider and perceived quality do not match. This is merely because consumers are no experts in this domain and thus the quality sensed by them would form the basis for their consumption (Nguyễn \& Nguyễn, 2011).

Apart from that, Nguyễn \& Nguyễn (2011) suggest that a brand perceived to have high quality will evoke consumers' feelings due to desirable features the brand offers 
that make them long to possess rather than any others. On the other hand, as confirmed by Zeihaml (1988) as a part of brand value, the higher perceived quality, the more likely a brand is chosen instead of other competing ones. Now that perceived quality is a component of brand equity (Aaker, 1991, 1996; Yoo et al., 2000; Nguyễn \& Nguyễn, 2011), hypothesis $\mathrm{H}_{3}$ is constructed as follows:

\section{$H_{3}$ : Perceived quality directly affects brand equity (+).}

Brand Loyalty: According to David Aaker (1991), brand loyalty is consumer's further engagement with a brand.

There are two brand loyalty approaches which are based on: (i) consumer's behavior; and (ii) consumer's attitude (Chaudhuri \& Holbrook, 2001; Kabiraj \& Shanmugan, 2011).

The first approach examining behavioral brand loyalty lays great emphasis on the loyalty to a brand with regard to repeat purchase or frequent use of a specific product of the brand (Chaudhuri \& Holbrook, 2001; Kabiraj \& Shanmugan, 2011). Per Oliver (1997), brand loyalty is considered an individual customer's commitment to the purchase or use of a branded product in the future despite the effects of the market's contexts and impacts which may change his or her unusual behaviors.

Definitions of attitudinal brand loyalty underscore consumer's intentions of consuming products. Rossiter \& Percy (1987) stress that brand loyalty is expressed through sympathetic attitudes toward a brand and aims of using the brand over times. Additionally, Yoo et al. (2001) suggest that brand loyalty signifies the tendency of consumer's loyalty to a brand.

Brand loyalty performs a key role in brand success and the more intensely brand loyalty is created, the more benefits it should bring (Nguyễn \& Nguyễn, 2011). For such reason, brand loyalty constitutes another component of brand equity (Aaker, 1991, 1996; Yoo et al., 2000; Nguyễn \& Nguyễn, 2011).

This study explores consumer's brand loyalty on the basis of attitudinal perspective. Thus, $\mathrm{H}_{4}$ can be formed as below:

\section{$H_{4}$ : Brand loyalty directly affects brand equity (+).}

In their study of brand equity, Yoo et al. (2000) assume that there exist interactions between its components. Aaker (1991) and Tan et al. (2011) further clarify that brand loyalty is also impacted by such other components of brand equity as brand awareness, 
brand associations, and perceived quality. Hence, the authors suggest the following hypotheses:

$H_{5}:$ Brand awareness directly affects brand loyalty (+).

$H_{6}$ : Brand associations directly affect brand loyalty (+).

$H_{7}$ : Perceived quality directly affects brand equity (+).

Also, to perceive brand quality, consumers must be aware of it, that is, they do not only identify the brand but are able to compare and distinguish it from other competing ones in the same group (Nguyễn \& Nguyễn, 2011). Once brand awareness and perceived quality are well experienced, consumer's brand associations would more conveniently be formed (Tong et al., 2009; Yoo et al., 2000), and this allows the authors to propose the following hypotheses:

$H_{5}$ : Brand awareness directly affects perceived quality (+).

$H_{6}$ : Brand awareness directly affects brand associations (+).

$H_{7}$ : Perceived quality directly affects brand associations (+).

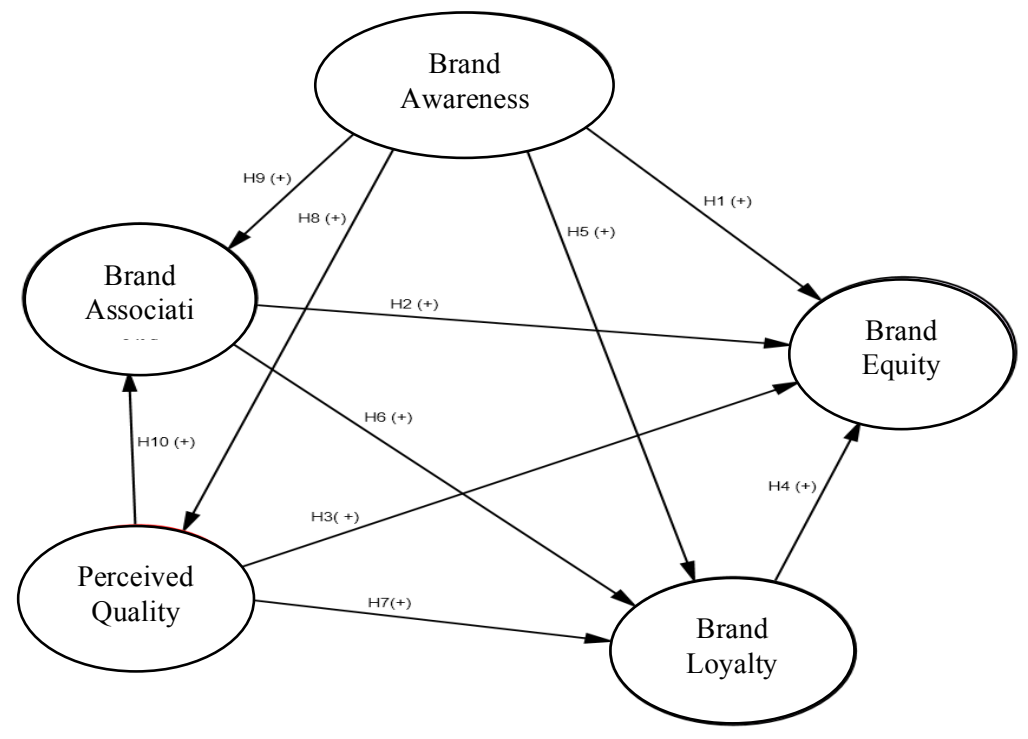

Figure 1: Proposed Model and Hypotheses

Source: Authors' design 


\section{METHODOLOGY}

\subsection{Research Procedures}

The study combines quantitative and qualitative methods. Qualitative research features group discussion concerning 10 customers with regular purchase of Bình Thuận dragon fruit. Next, quantitative research is conducted, preliminarily with 100 respondents directly consuming the fruit, based on direct interviews by means of questionnaires to evaluate the consistency and scale structure. Initial results of quantitative research will subsequently be applied as the data used in the formal research.

The formal research proceeds with the participation of 400 respondents (including 338 valid responses) in HCMC and Phan Thiết City also based on questionnaires to test the research model and hypotheses:

In Phan Thiết City, respondents are regular Bình Thuận dragon fruit purchasers from Phan Thiết market, fruit stores, and tourist attractions (160 out of 200 responses are valid).

For the case of HCMC, respondents are also regular Bình Thuận dragon fruit purchasers in farm product markets, first-level supermarket, and fruit stores (178 out of 200 responses are valid).

\subsection{Measure}

The scales employed in this study are previously used in Aaker (1991, 1996), Lassar et al. (1995), Yoo et al. (2000, 2001) and Nguyễn \& Nguyễn (2001) to measure brand equity and its components. Yet, these scales are based on consumer or manufactured goods in developed countries and thus are inappropriate for dragon fruit brand in Vietnam's market. For this reason, quantitative and qualitative methods are used for adjusting the measure to this empirical research in Vietnam.

The results indicate that 25 observed variables used to measure brand equity and its related components of Bình Thuận dragon fruit include 7 variables for measuring brand awareness, 4 for brand associations, 4 for brand loyalty, 7 for perceived quality and 3 for overall brand equity, all of which are employed to design the questionnaires.

\subsection{Data Process Technique}


Collected data regarding Bình Thuận dragon fruit consumers are evaluated by means of Cronbach's Alpha, Explanatory Factor Analysis (EFA), Confirmatory Factor Analysis (CFA) and Structural Equation Modeling (SEM).

\section{RESEARCH RESULTS}

\subsection{Reliability Test for Scales of Studied Concepts}

Results of reliability test through Cronbach's Alpha: The conditions governing reliability standards include Cronbach's Alpha $>0,6$ and item-total correlation $>0.3$ (Nunnally \& Burnstein, 1994). Results of the test are illustrated in Table 1:

Table 1. Results of Reliability Test for Studied Concepts

\begin{tabular}{|c|c|c|c|c|c|}
\hline Observed Variable & $\begin{array}{c}\text { Scale } \\
\text { Mean If } \\
\text { Item } \\
\text { Deleted }\end{array}$ & $\begin{array}{c}\text { Scale } \\
\text { Variance } \\
\text { If Item } \\
\text { Deleted }\end{array}$ & $\begin{array}{c}\text { Corrected } \\
\text { Item-Total } \\
\text { Correlation }\end{array}$ & $\begin{array}{c}\text { Cronbach's } \\
\text { Alpha If } \\
\text { Item } \\
\text { Deleted }\end{array}$ & Source \\
\hline \multicolumn{6}{|c|}{ Perceived Quality $(\mathrm{QL})$ : Alpha $=0.89$} \\
\hline QL1: The shape of Bình & & & & & \multirow{8}{*}{$\begin{array}{l}\text { Yoo et al. } \\
(2000) ; \text { Nguyễn } \\
\text { \& Nguyễn } \\
(2011)\end{array}$} \\
\hline $\begin{array}{l}\text { Thuận dragon fruit is so } \\
\text { beautiful. }\end{array}$ & 22.0030 & 11.9377 & 0.7132 & 0.8725 & \\
\hline QL2: Its colors are brilliant. & 21.9172 & 11.7973 & 0.7056 & 0.8734 & \\
\hline QL3: It is tasty and sweet. & 21.8994 & 11.8177 & 0.6865 & 0.8760 & \\
\hline $\begin{array}{l}\text { QL4: Its flavor is pure and } \\
\text { refreshing. }\end{array}$ & 21.7485 & 12.1651 & 0.6870 & 0.8757 & \\
\hline $\begin{array}{l}\text { QL5: It offers high nutritional } \\
\text { value. }\end{array}$ & 21.8580 & 12.2409 & 0.6890 & 0.8755 & \\
\hline $\begin{array}{l}\text { QL6: It can be long-term } \\
\text { preserved. }\end{array}$ & 21.9260 & 12.3417 & 0.6706 & 0.8776 & \\
\hline $\begin{array}{l}\text { QL7: It satisfies my demands } \\
\text { for consuming dragon fruit. }\end{array}$ & 21.8077 & 12.2864 & 0.6648 & 0.8783 & \\
\hline \multicolumn{5}{|c|}{ Brand awareness AW: Alpha $=0.871$} & \multirow{2}{*}{$\begin{array}{l}\text { Yoo et al. } \\
(2000) \\
\text { Aaker (1991) }\end{array}$} \\
\hline $\begin{array}{l}\text { AW1: I am aware of Bình } \\
\text { Thuận dragon fruit. }\end{array}$ & 20.6095 & 9.5800 & 0.6694 & 0.8492 & \\
\hline AW2: I am aware of how it & 20.3994 & 9.2851 & 0.7082 & 0.8437 & Nguyễn \& \\
\hline
\end{tabular}


looks like.

Nguyễn (2011)

AW3: I am aware of how it tastes.

$$
\begin{array}{llll}
20.8432 & 10.0080 & 0.6612 & 0.8514
\end{array}
$$

AW4: I can be aware of its colors.

$\begin{array}{llll}21.1036 & 9.7073 & 0.6338 & 0.8540\end{array}$

AW5: I can distinguish Bình Thuận dragon fruit from 20.8669 9.0831 0.6234 0.8590 other types.

AW6: I am aware of the design of its logo.

AW7: Briefly, when referring to Bình Thuận dragon fruit, I can easily conceive of it.

Brand associations AS: Alpha $=\mathbf{0 . 9 1 3}$

AS1: When mentioning dragon fruit, I immediately associate it with Bình Thuận $\begin{array}{llll}9.6331 & 4.6187 & 0.7807 & 0.8960\end{array}$ one.

AS2: I have no trouble in $\begin{array}{lllll}10.1538 & 4.2255 & 0.7948 & 0.8900 & \text { (2000) }\end{array}$ visualizing its shape and colors.

AS3: As for the fruit, I picture the one with a thick peel and long-term $\begin{array}{llll}10.4408 & 4.4727 & 0.7996 & 0.8889\end{array}$ preservation.

AS4: Its sweet and refreshing taste first comes to my mind in my reference to Bình $\begin{array}{llll}10.5296 & 3.8582 & 0.8487 & 0.8723\end{array}$ Thuận dragon fruit.

\section{Brand loyalty LO: Alpha $=\mathbf{0 . 8 5 1}$}

LO1: I always think of Bình Thuận brand when I want dragon fruit.
Yoo et al. (2000)

Lassar et al.

(1995)

Nguyễn \&

Nguyễn (2011) 
LO2: I will not buy any other brands if Bình Thuận dragon fruit is not available at fruit $\begin{array}{llll}10.5266 & 2.4340 & 0.7184 & 0.8020\end{array}$ stores.

LO3: I will purchase Bình Thuận dragon fruit in the $\begin{array}{llll}10.2219 & 2.7904 & 0.7050 & 0.8070\end{array}$ future.

LO4: I will introduce Bình Thuận dragon fruit to other $\begin{array}{llll}9.6183 & 2.6996 & 0.6980 & 0.8084\end{array}$ consumers.

\section{Brand equity BE: Alpha $=0.804$}

BE1: It is meaningful to consume Bình Thuận dragon fruit instead of other kinds $\begin{array}{llll}7.6213 & 0.8710 & 0.6732 & 0.7111\end{array}$ although this kind of fruit may seem the same.

BE2: Although many kinds of dragon fruit offer similar flavor, I like using Bình $\begin{array}{lllll}7.5799 & 0.9209 & 0.6838 & 0.6957 & (2000)\end{array}$ Thuận one.

BE3: Despite the presence of other brands of the same quality, I would stick to my choice of Bình Thuận dragon $\begin{array}{llll}7.2308 & 1.1157 & 0.6086 & 0.7781\end{array}$ fruit.

The results achieved from Cronbach's Alpha test demonstrate that the scales' reliability is ensured. All coefficients of item-total correlations are higher than 0.3 (the minimum is AW6 $=0.5871$. Cronbach's Alpha coefficients are all higher than 0.7. Thus, all of the observed variables can be employed in the next analysis.

Results of Explanatory Factor Analysis (EFA): EFA results suggest that 22 observed variables are drawn into 4 factors:

QL1, QL2, QL3, QL4, QL5, QL6 and QL7: Perceived Quality QL

AW1, AW2, AW3, AW4, and AW7: Brand awareness AW 
LO1, LO2, LO3, LO4: Brand loyalty LO

AS1, AS2, AS3, AS4, AW5, AW6: Brand associations AS (since factor loadings of $\mathrm{AS} 1, \mathrm{AS} 2, \mathrm{AS} 3$, and AS4 are the highest, these are the main factors creating the factor brand associations).

The results further indicate that AW5 and AW6, according to consumer's opinions, belong to brand associations and that $\mathrm{BE} 1, \mathrm{BE} 2$, and $\mathrm{BE} 3$ are incorporated into brand equity BE.

EFA results with Varimax rotation including Eigenvalue $>1$ and total variance extracted $>50 \%$ demonstrate that the five factors tested from the empirical model are consistent with the scales suggested in previous studies. EFA results are presented in detail in Tables 2 and 3.

Table 2. EFA Results of Brand Equity's Components

\begin{tabular}{|c|c|c|c|c|}
\hline \multirow{2}{*}{ Observed variable } & \multicolumn{4}{|c|}{ Factor } \\
\hline & 1 & 2 & 3 & 4 \\
\hline QL1 & 0.8063 & & & \\
\hline QL2 & 0.7470 & & & \\
\hline QL4 & 0.7389 & & & \\
\hline QL5 & 0.7292 & & & \\
\hline QL7 & 0.7252 & & & \\
\hline QL3 & 0.7238 & & & \\
\hline QL6 & 0.7179 & & & \\
\hline AS4 & & 0.8505 & & \\
\hline $\mathrm{AS} 2$ & & 0.8276 & & \\
\hline AS3 & & 0.7940 & & \\
\hline AS1 & & 0.7899 & & \\
\hline AW6 & & 0.5725 & & \\
\hline AW5 & & 0.5669 & & \\
\hline AW7 & & & 0.7648 & \\
\hline AW3 & & & 0.7592 & \\
\hline AW2 & & & 0.7517 & \\
\hline AW4 & & & 0.7510 & \\
\hline AW1 & & & 0.7495 & \\
\hline LO3 & & & & 0.7713 \\
\hline $\mathrm{LO} 2$ & & & & 0.7525 \\
\hline LO4 & & & & 0.7476 \\
\hline
\end{tabular}




\begin{tabular}{lcccc} 
LO1 & & & \\
\hline Eigenvalue & 4.3681 & 3.8203 & 3.6410 & 0.6940 \\
\hline \% of variance & 19.8551 & 17.3654 & 16.5501 & 12.3355 \\
\hline KMO & & & 0.9391 \\
Bartlett's Test & Chi square & & 4188.8215 \\
& df & & 231 \\
& Sig. & & \multicolumn{2}{c}{0.000} \\
\hline
\end{tabular}

Source: Authors' calculations

Table 3. EFA Results of Brand Equity

\begin{tabular}{|c|c|c|}
\hline \multirow{2}{*}{$\begin{array}{c}\text { Observed } \\
\text { variable }\end{array}$} & \multicolumn{2}{|c|}{ Factor } \\
\hline & \multicolumn{2}{|c|}{1} \\
\hline BE1 & \multicolumn{2}{|c|}{0.866} \\
\hline BE2 & \multicolumn{2}{|c|}{0.860} \\
\hline BE3 & \multicolumn{2}{|c|}{0.819} \\
\hline Eigenvalue & \multicolumn{2}{|l|}{2.161} \\
\hline$\%$ of variance & \multicolumn{2}{|l|}{72.030} \\
\hline KMO & \multicolumn{2}{|l|}{0.705} \\
\hline \multirow[t]{3}{*}{ Bartlett's Test } & Chi square & 330.438 \\
\hline & df & 3 \\
\hline & Sig. & 0.000 \\
\hline
\end{tabular}

Source: Authors' calculations

CFA Results: Composite reliability and extracted variance concerning scales of the concepts of brand equity's components show that the scales' reliability satisfies value conditions as illustrated in Table 4. 
Table 4. CFA Results

\begin{tabular}{|c|c|c|c|c|c|}
\hline \multirow{2}{*}{ Concept } & \multirow{2}{*}{ Component } & \multirow{2}{*}{$\begin{array}{c}\text { Number } \\
\text { of } \\
\text { observed } \\
\text { variables }\end{array}$} & \multicolumn{2}{|c|}{ Reliability } & \multirow{2}{*}{$\begin{array}{c}\text { Extracted } \\
\text { variance }\end{array}$} \\
\hline & & & Cronbach & Composite & \\
\hline \multirow{4}{*}{$\begin{array}{l}\text { Brand } \\
\text { equity's } \\
\text { components }\end{array}$} & Perceived quality QL & 7 & 0.891 & 0.892 & 0.541 \\
\hline & Brand awareness AW & 5 & 0.871 & 0.855 & 0.541 \\
\hline & Brand associations & 6 & 0.913 & 0.911 & 0.634 \\
\hline & Brand loyalty & 4 & 0.851 & 0.854 & 0.593 \\
\hline \multicolumn{2}{|c|}{ Brand equity BE } & 3 & 0.804 & 0.808 & 0.584 \\
\hline
\end{tabular}

Source: Authors' analysis

A correlation test among the scales signifies that Chi-square $=313.895$, $\mathrm{df}=203$ with $\mathrm{p}=0.000$. However, other indexes demonstrate the model's consistency with market data: $\mathrm{TLI}=0.969$; CFI $=0.971$ and $\mathrm{RMSEA}=0.040$ satisfy the conditions of level of consistency as presented in Table 5.

Table 5. Fit Index Method for Testing Discriminant Validity of the Factors

\begin{tabular}{lccccccc}
\hline \multicolumn{1}{c}{ Indexes } & $\chi \mathbf{2}$ & $\mathbf{d f}$ & $\chi \mathbf{2} / \mathbf{d f}$ & $\mathbf{p}$-value & TLI & CFI & RMSEA \\
\hline $\begin{array}{l}\text { Model value } \\
\begin{array}{l}\text { Acceptable model fit } \\
\text { value }\end{array}\end{array}$ & & 203 & 1.546 & 0.000 & 0.969 & 0.971 & 0.040 \\
\hline
\end{tabular}

$\chi 2 /$ d.f. ratio $<2$ (Nguyễn \& Nguyễn, 2011), TLI > 0.90 (Hair et al., 2006), CFI > 0.95 (Hu \& Bentler, 1999), RMSEA < 0.07 (Hair et al., 2006), p-value > 0.05 (Nguyễn \& Nguyễn, 2011)

\subsection{Model and Hypotheses Tests:}

The results of estimation of theoretical model presented in Table 6 show that $\chi 2$ of 378.744 , df of 265 with a p-value of $0.000(<0,05)$ do not meet the expectations due to sample size. However, other indexes imply the model's consistency with market data: $\mathrm{TLI}=0.972 ; \mathrm{CFI}=0.976$ and RMSEA $=0.036$. The results of the empirical research on Bình Thuận dragon fruit brand equity are compliant with theoretical models suggested by Aaker $(1991,1996)$. The results of model and hypotheses tests are in Figure 2 . 
Table 6. Fit Index Method for Testing the Research Model

\begin{tabular}{lccccccc}
\hline \multicolumn{1}{c}{ Indexes } & $\chi \mathbf{2}$ & Df & $\chi \mathbf{2} / \mathbf{d f}$ & $\begin{array}{c}\mathbf{p}- \\
\text { value }\end{array}$ & TLI & CFI & RMSEA \\
\hline Model value & 378.744 & 265 & 1.429 & 0.000 & 0.972 & 0.976 & 0.040 \\
Acceptable model fit value & & & $<2$ & $>0.05$ & $>0.90$ & $>0.95$ & $<0.070$ \\
\hline
\end{tabular}

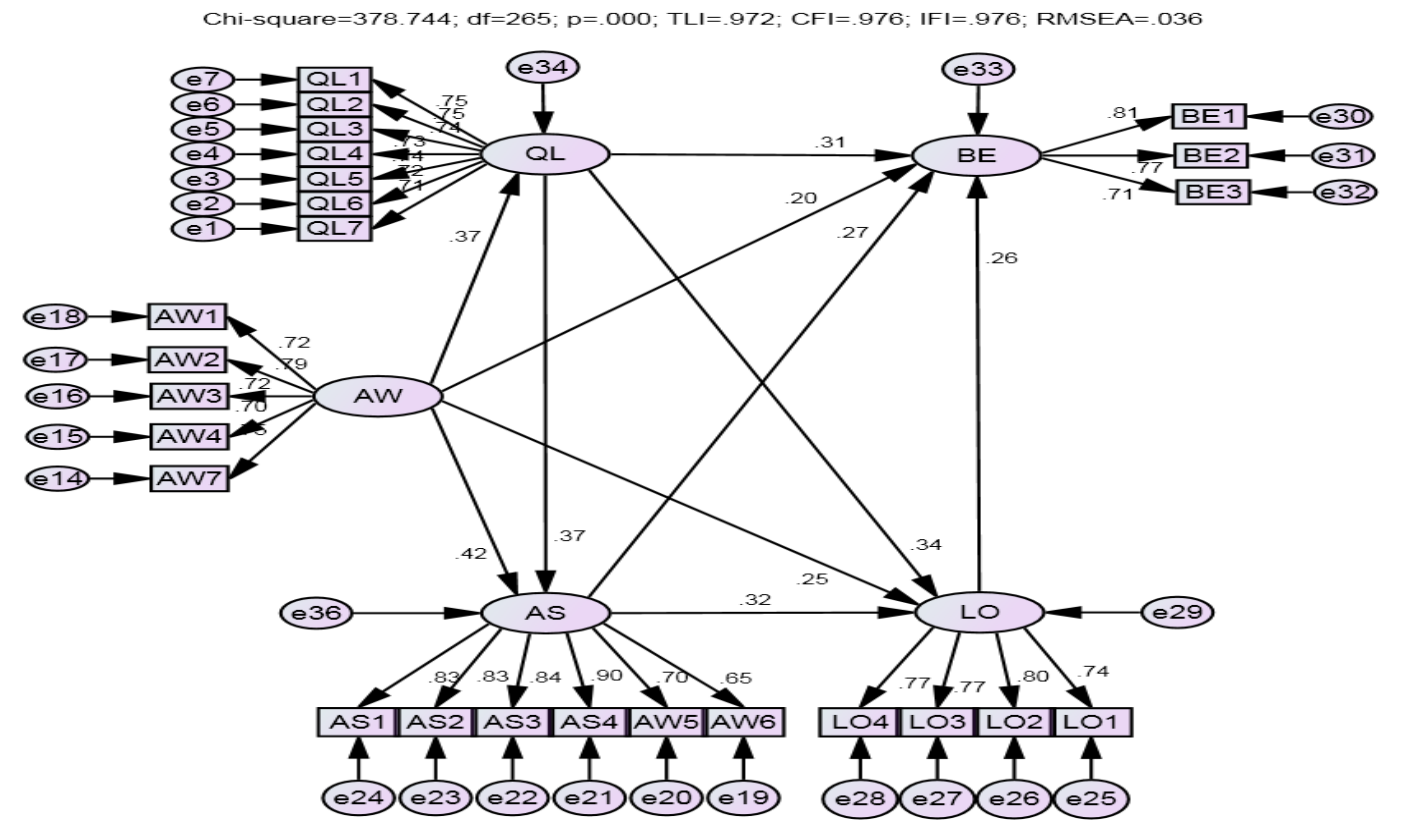

$\chi 2 /$ d.f. ratio $<2$ (Nguyễn \& Nguyễn, 2011), TLI > 0.90 (Hair et al., 2006), CFI > 0.95 (Hu \& Bentler, 1999), RMSEA < 0,07 (Hair et al., 2006), p-value > 0.05 (Nguyễn \& Nguyễn, 2011)

Figure 2. Results of Model and Hypotheses Testing

Table 7 demonstrates the results of the hypotheses testing, which indicate that all of the hypotheses are accepted at 0.05 significance level. 
Table 7. Results of Hypotheses Testing

\begin{tabular}{cccccccc}
\hline & & & Estimate & S.E. & C.R. & P & Label \\
\hline QL & $<---$ & AW & 0.37 & 0.065 & 5.67 & 0.000 & $\mathrm{H}_{8}$ accepted \\
AS & $<---$ & AW & 0.295 & 0.045 & 6.581 & 0.000 & $\mathrm{H}_{9}$ accepted \\
AS & $<---$ & QL & 0.259 & 0.043 & 6.049 & 0.000 & $\mathrm{H}_{10}$ accepted \\
LO & $<---$ & QL & 0.3 & 0.055 & 5.437 & 0.000 & $\mathrm{H}_{7}$ accepted \\
LO & $<---$ & AW & 0.219 & 0.056 & 3.917 & 0.000 & $\mathrm{H}_{5}$ accepted \\
LO & $<---$ & AS & 0.403 & 0.088 & 4.586 & 0.000 & $\mathrm{H}_{6}$ accepted \\
BE & $<---$ & QL & 0.292 & 0.059 & 4.964 & 0.000 & $\mathrm{H}_{3}$ accepted \\
BE & $<---$ & AW & 0.188 & 0.057 & 3.281 & 0.001 & $\mathrm{H}_{1}$ accepted \\
BE & $<---$ & AS & 0.359 & 0.09 & 3.994 & 0.000 & $\mathrm{H}_{2}$ accepted \\
BE & $<---$ & LO & 0.281 & 0.079 & 3.555 & 0.000 & $\mathrm{H}_{4}$ accepted \\
\hline
\end{tabular}

Source: Authors' analysis

\section{RESULT DISCUSSIONS AND RESEARCH IMPLICATIONS}

\subsection{Result Discussions}

The results show that brand equity's components of Bình Thuận dragon fruit are correlated with one another:

Brand awareness AW affects perceived quality QL as for Bình Thuận dragon fruit brand $\left(\right.$ Hypothesis $\mathrm{H}_{8}$ ), consistent with the theory and empirical research by Tong et al., 2009 and Yoo et al., 2000.

Brand awareness AW and perceived quality QL directly affect brand associations AS (Hypotheses $\mathrm{H}_{9}$ and $\mathrm{H}_{10}$ ), consistent with the theory and empirical research by Tong et al. (2009) and Yoo et al. (2000).

Brand awareness AW, perceived quality QL, and brand associations directly affect customer's loyalty to the brand (Hypotheses $\mathrm{H}_{5}, \mathrm{H}_{6}$, and $\mathrm{H}_{7}$ ), consistent with the theory and empirical research by Aaker (1991), Yoo et al. (2000), and Tan et al. (2011).

Furthermore, these components do affect brand equity BE (Hypotheses $\mathrm{H}_{1}, \mathrm{H}_{2}, \mathrm{H}_{3}$, and $\mathrm{H}_{4}$ ), consistent with the theory and empirical research by Aaker $(1991,1996)$, Keller (1993, 1998), Yoo et al. (2000), and Nguyễn \& Nguyễn (2011). 
The results also indicate that perceived quality QL greatly affects brand equity $\mathrm{BE}$ and brand loyalty LO. These imply that the research should take account of perceived quality of Bình Thuận dragon fruit brand.

\subsection{Research Implications}

Based on the study results, the authors suggest the following policy implications for enhancing perceived quality: (1) Improving the quality of dragon fruit to satisfy market demands by applying technology to production, harvest and preservation thereby ensuring consistent quality of shape and good preservation for the fruit; (2) Developing technological process of care, harvest and preservation and popularize such knowledge to producers; (3) Strictly controlling food hygiene according to VietGap standards.

In addition, several implications are proposed to foster consumer's brand awareness and associations, including the following:

(1) Advertise health benefits offered by the dragon fruit to stimulate consumer tastes and preferences and broaden market size;

(2) Develop distribution networks including wholesale markets and supermarkets to promote consumption and expand market share;

(3) Consult provincial trade promotion agencies for recommendations on reputable and qualified fruit traders, thereby helping Bình Thuận dragon fruit suppliers engage in promotional activities such as trade negotiations, market research and opportunity seeking to expand their market; and

(4) Widely promote the brand through video clips, reports on mass media and reliable websites to promote consumer preference for Bình Thuận dragon fruit.

\subsection{Limitations and Suggestions for Further Studies}

The study focuses only on direct consumers, not on indirect ones (retailers and wholesalers), while in fact the latter does exert certain influences on brand equity. Thus, there should be further studies on brand equity that combines both direct and indirect consumers.

Due to time and budget constraints, the research has been carried out with only 400 respondents (338 valid responses) in HCMC and Phan Thiết City based on convenient sampling method, which proves a hindrance to the tests on reliability of the scales 


\section{References}

Aaker, D.A. (1991), Managing Brand Equity, New York: The Free Press

Aaker, D.A. (1996), Building Strong Brands, New York, NY.

Atilgan, E., S. Akinci, S. Aksoy \& E. Kaynak (2005), "Determinants of the Brand Equity: A Verification Approach in the Beverage Industry in Turkey", Marketing Intelligence \& Planning, 23(3): 237-248.

Berry, L. (2000), "Cultivating Service Brand Equity", Academy of Marketing Science Journal, Winter 2000, 28(1): 128-137.

Blackston, M. (1992), “Observations: Building Brand Equity by Managing the Brand's Relationships", Journal of Advertising Research, 32(3): 79-83.

Brown, J.R., R.F. Lusch \& L.P. Smith (1991), "Conflict and Satisfaction in an Industry Channel and Distribution", International Journal of Physical Distribution and Logistics Management, 21(6): $15-26$.

Chahal, H. \& M. Bala (2012), "Significant Components of Service Brand Equity in Healthcare Sector", International Journal of Health Care Quality Assurance, 25(4): 343-362.

Chaudhuri, A. (1999), "Does Brand Loyalty Mediate Brand Equity Outcomes", Journal of Marketing Theory and Practice, 7(2): 136-146.

Chen, A.C. (2001), "Using Free Association to Examine the Relationship between the Characteristics of Brand Associations and Brand Equity", Journal of Product \& Brand Management, 10(6/7): 439-449.

Bình Thuận Office of Statistics (2012), Niêm giám thống kê tỉnh Bình Thuận.

Davis, S. \& D. Doughlass (1995), "Holistic Approach to Brand Equity Management", Marketing News, 29(2): 4-5.

Edell, J. (1993), “Advertising Interactions: A Route to Understanding Brand Equity", in A.A. Mitchell (ed.), Advertising Exposure, Memory and Choice, NJ: Hillsdale: 195-208

Hair, J., R. Aderson, P. Tatham \& W. Black (2006), Multivariate Data Analysis, $6^{\text {th }}$ ed., N.J: Prentice- Hall, Upper Saddle River.

Hoàng Thị Phương Thảo, Hoàng Trọng \& Chu Nguyễn Mộng Ngọc (2009), Phát triển sự đo luờng tài sản thuoong hiệu trong thị truoòng dịch vu, Ministerial-level research project, HCM University of Economics.

Hu, L.T. \& P.M. Bentler (1999), "Cutoff Criteria for Fit Indexes in Covariance Structure Analysis: Conventional Criteria versus New Alternatives", Structural Equation Modeling, 6(1): 1-55.

Kabiraj, S. \& J. Shanmugan (2011), "Development of a Conceptual Framework for Brand Loyalty: A Euro Mediterranean Perspective, Journal of Brand Management, 18: 285-299.

Keller, K.L. (1993), "Conceptualizing, Measuring, and Managing Consumer - Based Brand Equity", Journal of Marketing, 57: 1-22.

Keller, K.L. (1998), Strategic Brand Management: Building, Measuring and Managing Brand Equity, N.J.: Prentice-Hall, Englewood Cliffs.

Lassar, W., B. Mittal \& A. Sharma (1995), "Measuring Consumer - Based Brand Equity", Journal of Consumer Marketing, 12(4): 4-11. 
Nguyễn Đình Thọ \& Nguyễn Thị Mai Trang (2011), "Giá trị thương hiệu trong thị trường hàng tiêu dùng”, in Nghiên cưu khoa học Marketing: Úng dụng mô hình cấu trúc tuyến tính SEM, $\left(2^{\text {nd }}\right.$ ed.), HCMC: Lao động, 3-85.

Nunnally J.C. \& I.H. Burnstein (1994), Psychometric Theory, $3^{\text {rd }}$ ed., New York: McGraw-Hill.

Oliver, R.L. (1997), A Behavioral Perspective on the Consumer, New York: McGraw-Hiil.

Park, C.S. \& V. Srinivasan (1994), “A Survey-Based Method for Measuring and Understanding Brand", Journal of Marketing Research, 31(2): 271-288.

Rossiter, J.R. \& L. Percy (1987), Advertising and Promotion Management, New York: McGrawHill.

Saydan, R. (2013), "Relationship between Country of Origin Image and Brand Equity: An Empirical Evidence in England Market", International Journal of Business and Social Science, 4(3): 78-88.

Sharp, B. (1995), "Brand Equity and Market-Based Assets of Professional Service Firms" Journal of Professional Services Marketing, 13(1): 3-13.

Silverman, S.N., D.E. Sprott \& V.J. Pascal (1999), "Relating Consumer-Based Sources of Brand Equity to Market Outcomes", Advances in Consumer Research, 26: 352-358.

Simon, C.J. \& M.W. Sullivan (1993), "The Measurement and Determinants of Brand Equity: A Financial Approach", Marketing Science, 12(1): 28-52.

Bình Thuận Department of Agriculture and Rural Development (2010), Báo cáo tình hình sản xuất thanh long trên địa bàn tỉnh; Phương huoóng triển khai trong thòi gian tới.

Srivastava, R.K. \& A.D. Shocker (1991), "Brand Equity: A Perspective on Its Meaning and Measurement", Marketing Science Institute Report, (91-124), Marketing Science Institute Cambridge, MA.

Tan Teck Ming, Hishamuddin Bin Ismail \& Devinaga Rasiah (2011), "Hierarchical Chain of Consumer-Based Brand Equity: Review from the Fast Food Industry", International Business \& Economics Research Journal, 10(9): 67-79.

Tong, X. \& J. Hawley (2009), "Measuring Customer-Based Brand Equity: Empirical Evidence from the Sportswear Market in China", Journal of Product and Brand Management, 18(4): 262-271.

Yoo, B., N. Donthu \& S. Lee (2000), "An Examination of Selected Marketing Mix Elements and Brand Equity”, Journal of the Academy of Marketing Science, 28(2): 195-211.

Zeithaml, V.A. (1988), "Consumer Perceptions of Price, Quality, and Value: A Means-End Model and Synthesis of Evidence", Journal of Marketing, 52(3): 2-22. 